National Marine

Fisheries Service

NOAA
Fishery Bulletin

ar established in 1881 o
Spencer F. Baird

First U.S. Commissioner of Fisheries and founder of Fishery Bulletin

\begin{abstract}
We analyzed the effect of skipped spawning on the estimates of length and age at maturity and on the reproductive potential of Argentine hake (Merluccius hubbsi) from the Patagonian stock during the spawning peaks between 2005 and 2013. The length at first maturity increased by $2-3 \mathrm{~cm}$ in total length (TL), and the age at maturity increased by $0.27-0.88$ years when the proportion of females that would skip spawning was incorporated in the relationships. In addition, the slopes of the models decreased, suggesting that all individuals reach sexual maturity at a greater size and age than those estimated with the traditional criterion for maturity, which does not consider skipped spawning because fish in the resting stage are classified as mature. The reduction in egg production caused by skipped spawning ranged between $3.56 \%$ and $12.12 \%$, when we used the maturity models with age data, or between $2.70 \%$ and $6.80 \%$, when we used the models with TL data. Females that would skip spawning were mainly specimens with sizes between 40 and $50 \mathrm{~cm}$ TL, and most belonged to the age class of 3-year-old fish.
\end{abstract}

Manuscript submitted 26 October 2016. Manuscript accepted 30 May 2017. Fish. Bull. 115:396-407 (2017). Online publication date: 13 June 2017. doi: 10.7755/FB.115.3.9

The views and opinions expressed or implied in this article are those of the author (or authors) and do not necessarily reflect the position of the National Marine Fisheries Service, NOAA.

\title{
Effects of skipped spawning on the reproductive potential of Argentine hake (Merluccius hubbsi)
}

\author{
Gustavo J. Macchi 1,2 (contact author) \\ Karina Rodrigues $\mathbf{1}^{\mathbf{2}}$ \\ Marina V. Diaz ${ }^{1,2}$ \\ María I. Militelli ${ }^{1,2}$ \\ Email address for contact author: gmacchi@inidep.edu.ar \\ 1 Consejo Nacional de Investigaciones Científicas y Técnicas (CONICET) \\ Instituto de Investigaciones Marinas y Costeras (IIMyC) \\ Rodríguez Peña 4002-4100 \\ B7602GSD Mar del Plata \\ Buenos Aires, Argentina \\ 2 Instituto Nacional de Investigación y Desarrollo Pesquero (INIDEP) \\ Paseo Victoria Ocampo Nro. 1 \\ B7602HSA Mar del Plata \\ Buenos Aires, Argentina
}

One of the main assumptions in fishery assessments for iteroparous fish species is that after spawning for the first time, i.e., after reaching maturity, these species reproduce annually. Nevertheless, failure to spawn in consecutive years has been observed in many species, a phenomenon known as skipped spawning (SS) (Rideout et al., 2005). In general, the hypotheses proposed to explain the cause of SS are associated with feeding deficiencies that decrease energy storage before spawning. Such feeding deficiencies may leave the fish in such a poor nutritional condition that they may not have sufficient energy to support egg production in consecutive years (Dutil, 1986; Holmgren, 2003; Jørgensen et al., 2006; Rideout et al., 2006; Rideout and Tomkiewicz, 2011). Failure to consider SS in the reproductive output of a stock could result in an overestimation of spawning stock biomass and reproductive potential (Rideout and Tomkiewicz, 2011). Despite the influence of the SS phenomenon in the estimation of total egg production, this influence has rarely been considered in fishery assessments (Rideout et al., 2005).
The Patagonian stock of Argentine hake (Merluccius hubbsi), distributed from $41^{\circ} \mathrm{S}$ to $55^{\circ} \mathrm{S}$ at depths between 50 and $500 \mathrm{~m}$, is one of the most important fishery resources for Argentina; the total annual catch reported for 2015 was approximately 260,000 metric tons (Ministerio de Agroindustria $^{1}$ ). This stock is assessed annually through virtual population analysis with an age-structured model with spawning stock biomass as a biological reference point. The Argentine hake from the Patagonian region is a batch spawner with indeterminate annual fecundity; it reproduces from November to April and peak spawning occurs in January (Macchi et al., 2004). Recently, it was reported that $6-22 \%$ of female Argentine hake from Patagonian waters would skip spawning and remain unproductive during the spawning peak (Macchi et

\footnotetext{
${ }^{1}$ Ministerio de Agroindustria. 2015 Desembarques de capturas marítimas totales-por especie y flota. Subsecretaría de Pesca y Acuicultura, Secretaría de Agricultura, Ganadería y Pesca, Ministerio de Agroindustria, Buenos Aires, Argentina. [Available from website, accessed October 2016.]
} 


\section{Table 1}

Number of samples and subsamples of specimens collected from the Patagonian stock of Argentine hake (Merluccius hubbsi), as well as the number of ovaries collected for estimation of fecundity. Research surveys were carried out during the spawning peak (January) and the resting period (August) of this stock in the north Patagonian region of Argentina from 2005 through 2013.

\begin{tabular}{lccccc}
\hline Year & $\begin{array}{c}\text { Total samples } \\
\text { in January }\end{array}$ & $\begin{array}{c}\text { Female samples } \\
\text { in January }\end{array}$ & $\begin{array}{c}\text { Female subsamples } \\
\text { in January }\end{array}$ & $\begin{array}{c}\text { Female samples } \\
\text { in August }\end{array}$ & $\begin{array}{c}\text { Ovaries } \\
\text { for fecundity }\end{array}$ \\
\hline 2005 & 16250 & 6810 & 2322 & 3228 & 178 \\
2006 & 8500 & 4022 & 2546 & & 111 \\
2007 & 8804 & 5634 & 2015 & 4371 & 78 \\
2008 & 13,881 & 7045 & 1954 & & 110 \\
2009 & 15,813 & 7970 & 1969 & & 101 \\
2010 & 19,683 & 9485 & 2037 & 5577 & 731 \\
2011 & 13,487 & 6420 & 1959 & 3030 & 82 \\
2012 & 19,362 & 9533 & 3448 & 7392 & 97 \\
2013 & 31,956 & 14,155 & 3361 & & \\
\end{tabular}

al., 2016). These individuals were located mostly on the periphery of the spawning area at depths close to 100 $\mathrm{m}$, and they were mainly young adult females.

We report on our continued study of skipped spawning in Argentine hake. The main purpose of the research described in our study was to establish how this phenomenon affects the reproductive potential of the Patagonian stock of this species. We constructed length- and age-based maturity models by using 2 interpretations of the maturity cycle: 1) females that had skipped spawning were classified as mature (traditional interpretation) and 2) mature females that had not spawned during the reproductive season were classified as functionally immature (revised interpretation). We also examined the relationship between the demographic composition of the stock and the incidence of skipped spawning. We estimated the proportion of the total reproductive potential that was reduced as a result of skipped spawning by analyzing data from research surveys performed during peak spawning of the Patagonian stock of Argentine hake.

\section{Materials and methods}

\section{Sample collection and laboratory processing}

Most of our samples were collected in the summer during 9 research surveys conducted by the Instituto $\mathrm{Na}$ cional de Investigación y Desarrollo Pesquero (INIDEP) in the north Patagonian area off Argentina between 2005 and 2013 (Table 1). These surveys were performed during the peak spawning time for the Patagonian stock of Argentine hake (January) in the area of reproduction, and in the main nursery ground for young-ofthe-year individuals in the San Jorge Gulf. Trawling during these surveys was conducted at depths between 50 and $120 \mathrm{~m}$ along transects regularly separated by approximately $37 \mathrm{~km}$ (20 $\mathrm{nmi})$ and oriented perpendicularly to the coastline (Fig. 1). We also had data from samples of females collected during 5 surveys carried out in the same area $\left(43-47^{\circ} \mathrm{S}\right.$ and $\left.61-67^{\circ} \mathrm{W}\right)$ in August (austral winter) when the Patagonian stock of Argentine hake was in a resting reproductive stage (Table 1). In these 5 surveys, 50-90 stations were sampled by using a stratified random design for the entire study area, at depths between 50 and $200 \mathrm{~m}$. The bottom trawl used for all surveys had a mouth width of approximately $20 \mathrm{~m}$, a height of $4 \mathrm{~m}$, and a net with a 20-mm mesh liner in the codend.

After weighing the catch of Argentine hake, a random sample was taken to determine sex, and the total length (TL, in centimeters) was recorded for each fish. Moreover, the maturity of each specimen was assessed macroscopically on the basis of a 5-stage maturity key: 1) immature, 2) developing, 3) spawning, 4) postspawning or spent, and 5) resting or recovering. This maturity scale was previously validated for females by histological analysis of the ovaries and was described in Macchi et al. (2016). For this reason, to estimate length and age at maturity ( $L_{50}$ and $A_{50}$, respectively), we used only macroscopic information. To estimate age composition, sagittal otoliths were collected from random subsamples of female Argentine hake collected from different sampling stations during January surveys (Table 1). Ages, based on analysis of these otoliths, were determined by using a method described by Renzi and Pérez (1992).

To estimate models of batch fecundity versus TL and batch fecundity versus age for the Patagonian stock, we collected females classified as spawning (with hydrated oocytes) from different sampling stations, and fixed the ovaries in $10 \%$ neutral-buffered formalin for histological analysis (Table 1). The ovaries were weighed to the nearest $0.1 \mathrm{~g}$ to obtain gonad weight, and a portion (approximately $2.0 \mathrm{~g}$ ) of each gonad was then removed, 


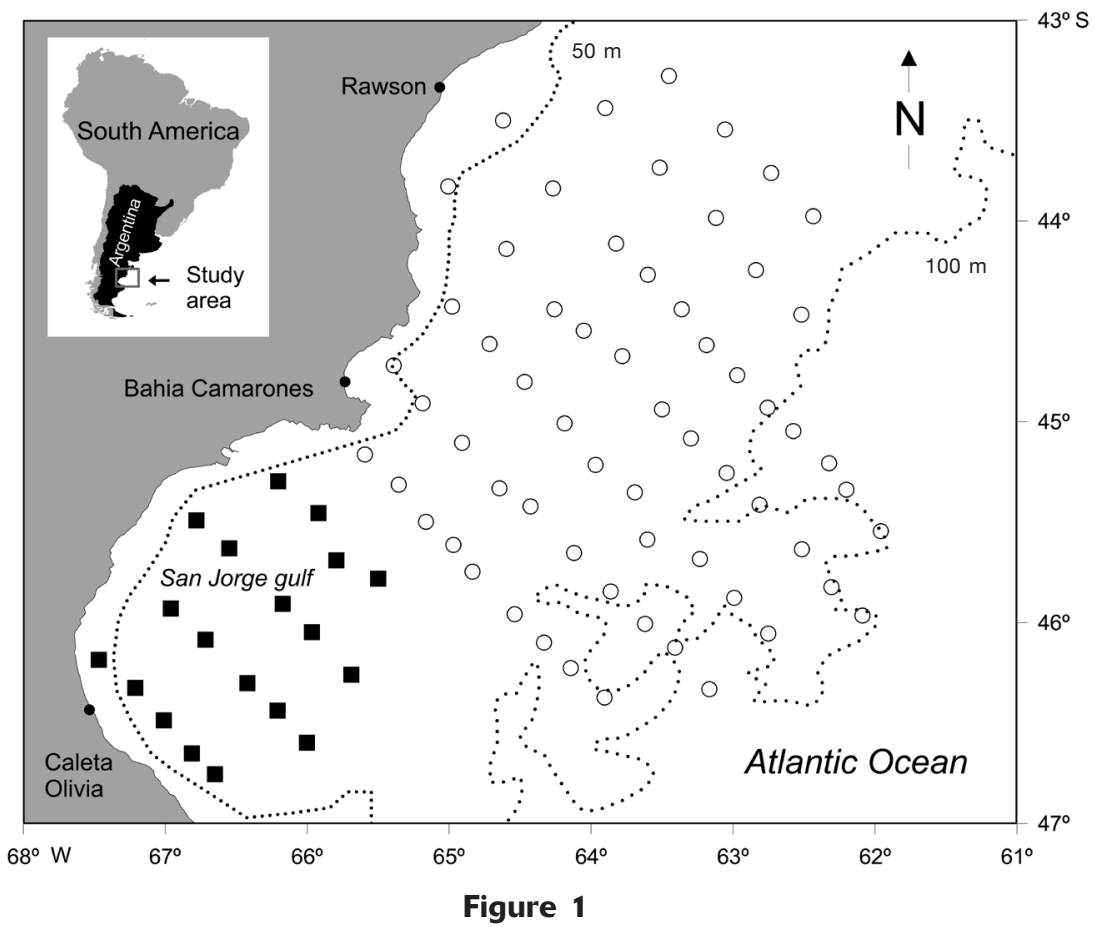

Locations where Argentine hake (Merluccius hubbsi) were collected during January for the years 2005 through 2013 in waters of the north Patagonian area off Argentina. Open circles indicate sampling locations in the area where Argentine hake typically spawn, and black squares indicate sampling locations in the nursery area for juvenile Argentine hake in the San Jorge Gulf.

dehydrated in ethanol, cleared in xylol, and embedded in paraffin. From these gonads, $5-\mu \mathrm{m}$ sections were mounted and stained with Harris hematoxylin followed by eosin counterstain.

\section{Estimation of length and age at maturity}

We constructed length- and age-based maturity ogives for female Argentine hake from samples and subsamples collected during the summer spawning peak (January) of the Patagonian stock (Table 1). For estimation of $L_{50}$ and $A_{50}$, the maximum likelihood method was used to fit the proportion of mature individuals by length class (TL) and age class to a logistic function (Kendall and Stuart, 1967).

The presence of ovaries in fish classified in the resting stage and collected during the main spawning peak of the Patagonian stock was taken as evidence of SS in female Argentine hake (Macchi et al., 2016). These gonads were characterized as having only oocytes in the primary growth phase and as having a thick ovarian tunica, with no evidence of ovary development or recent spawning (Rodgveller et al., 2016). Therefore, when considering SS in estimating the maturity ogives, we classified females in the resting stage as immature individuals.

For this reason, and following the method of Rodgveller et al. (2016), we estimated $L_{50}$ and $A_{50}$ on the basis of the following 2 interpretations of the matu- rity cycle: 1) the traditional interpretation, in which fish in the resting stage were classified as mature, and 2) the revised interpretation, in which adult females classified as in the resting stage were considered to be functionally immature. We obtained coefficients of the maturity ogives by using both interpretations for each year during the period 2005-2013. The coefficients were compared by using an $\chi^{2}$ test according to Aubone and Wöhler. ${ }^{2}$

In the case of the August surveys, we had only data for TL and gonad maturity stage from samples of females collected in 2005, 2007, 2011, 2012 and 2013 (Table 1). Using this information, we constructed lengthbased maturity ogives for August of those years, and the models obtained were compared with the maturity ogives estimated using data from January of the same year, during the previous spawning peak. Coefficients of the logistic relationships obtained in both sampling seasons were compared by using an $\chi^{2}$ test. It was not possible to identify females that were skipping spawning during August because the majority of the fish during this month were in a resting or immature stage.

\footnotetext{
2 Aubone, A., and O. Wöhler. 2000. Aplicación del método de máxima verosimilitud a la estimación de parámetros y comparación de curvas de crecimiento de von Bertalanffy. INIDEP Inf. Téc. 37, 21 p. [Available from Instituto Nacional de Investigación y Desarrollo Pesquero, Paseo Victoria Ocampo Nro. 1, B7602HSA Mar del Plata, Argentina.]
} 
Therefore, to estimate length at first maturity with data from the August survey, only the traditional interpretation of maturity assignment (resting stage as mature female) was employed.

\section{Estimation of size and age distributions of female Argentine hake}

The number of females was estimated from data collected during each survey between 2005 and 2013 . These cruises covered a wide geographic range from $43^{\circ} \mathrm{S}$ to $47^{\circ} \mathrm{S}$, but to analyze the abundance of females that would skip spawning or would spawn, we used only data from sampling stations located in the area of active reproduction, which covers approximately $65 \%$ of the study zone (Fig. 1). The same area, with an extension of about $50,000 \mathrm{~km}^{2}$, is assessed every year during a fixed-station trawl survey to estimate the potential egg production of the Patagonian stock of Argentine hake (Macchi et al. ${ }^{3}$ ). Information obtained from sampling the trawl catch was expanded to obtain estimates of the number of individuals per length class, by using the method described by Macchi et al. (2004). The number of mature females for each survey was estimated by multiplying the number of Argentine hake within each length class by the proportion of mature females estimated from the $L_{50}$ ogive obtained for each survey. To obtain the incidence of SS by length class, we compared the length distributions obtained with the estimated maturity ogive with the traditional interpretation and the revised interpretation for each year.

From the age-length keys obtained with data collected in each survey, we estimated the age distributions of female Argentine hake in the sampling area during each January between 2005 and 2013. The number of mature females by age class for each year was estimated by multiplying the number of females in each age class by the proportion of mature females obtained from the $A_{50}$ ogive corresponding to that year. We compared the age distributions of mature females by using the maturity ogive constructed with the traditional and the revised interpretation. In this case, to determine the effect of spawning omission, we estimated the average age distributions obtained after grouping all years sampled during the period 2005-2013.

\section{Estimation of reproductive potential}

Because the Argentine hake is a batch spawner with indeterminate annual fecundity, we estimated the batch fecundity (number of oocytes released per spawning) by the hydrated oocyte method of Hunter et al. (1985).

\footnotetext{
${ }^{3}$ Macchi, G. J., M. Estrada, H. Brachetta, and V. Abachián 2013. Estructura y producción potencial de huevos del efectivo desovante de merluza (Merluccius hubbsi) al sur de $41^{\circ} \mathrm{S}$ durante enero de 2013. Inf. Téc. 88, 12 p. [Available from Instituto Nacional de Investigación y Desarrollo Pesquero, Paseo Victoria Ocampo Nro. 1, B7602HSA Mar del Plata, Argentina].
}

After histological diagnosis, we selected only ovaries with hydrated oocytes and without evidence of recent spawning (no postovulatory follicles), and removed 3 pieces of tissue $(0.1-0.2 \mathrm{~g}$ each) from the anterior, middle and posterior parts of a gonad. These samples were weighed (to the nearest $0.1 \mathrm{mg}$ ), and the number of hydrated oocytes was counted to estimate the mean of hydrated oocytes per unit of weight. Batch fecundity value for each female was obtained by multiplying the mean number of hydrated oocytes and the total weight of the ovaries. The relationships of batch fecundity to TL and age were described by using standard regression analysis (Draper and Smith, 1981).

We could not estimate a relationship between spawning frequency and TL or age for each year sampled. For this reason, the index of reproductive potential of the Patagonian stock of Argentine hake in January from 2005 to 2013 was estimated by multiplying the number of mature females in each length class or each age class by the batch fecundity corresponding to that length class or age class. Therefore, this index represents the egg production of the stock during one spawning event.

Estimates of egg production, by TL and age, by using the maturity ogive created with the traditional interpretation and the ogive created with the revised interpretation were compared to obtain the percentage of reduction in egg production attributed to nonreproductive adult females during the spawning season by year.

\section{Results}

\section{Length and age at maturity}

When we applied the traditional interpretation for maturity diagnosis, the $L_{50}$ estimates for females of Argentine hake during January 2005-2013 ranged between 32.22 and $34.53 \mathrm{~cm}$ TL (Table 2). However, when we used the revised interpretation and considered that females in a resting stage were individuals that had skipped spawning, the values of $L_{50}$ increased to range of $34.57-38.01 \mathrm{~cm}$ TL. In all cases, the standard error of $L_{50}$ was lower when SS was considered for estimation of the maturity ogives-a result that may be associated with the increase in the number of immature individuals in length classes close to $L_{50}$. In addition, when SS was included in the $L_{50}$ estimate, the slope of the logistic model decreased (Table 2), suggesting that all females reached sexual maturity at larger sizes than those estimated with the traditional interpretation. Comparison of the maturity ogives estimated by the different interpretations of maturity showed highly significant differences for all years sampled $(P<0.001)$.

The $A_{50}$ curves estimated with samples collected between 2005 and 2013 showed a similar pattern after inclusion of the proportion of females that SS in relationship both to the $A_{50}$ and the slope of the models. The $A_{50}$ values estimated with the traditional inter- 


\section{Table 2}

Length at maturity $\left(L_{50}\right)$ and slope $(b)$ determined by the logistic model for female Argentine hake (Merluccius hubbsi) from the Patagonian stock. Samples were collected during research surveys conducted off Argentina during the spawning peak (January) and resting period (August) of this stock, 2005-2013. For surveys conducted in January, coefficients of the models were estimated on the basis of the following 2 interpretations of the maturity cycle: 1 ) the traditional interpretation, in which females in the resting stage were classified as mature, and 2) the revised interpretation, in which females in the resting stage were considered to be functionally immature. Lengths were measured as total length in centimeters. Standard errors of the means are given in parentheses. $n=$ sample size. TI, traditional interpretation; RI, revised interpretation.

\begin{tabular}{|c|c|c|c|c|c|c|}
\hline Year & Month & $\begin{array}{c}L_{50}(\mathrm{~cm} \mathrm{TL}) \\
\mathrm{TI}\end{array}$ & $\begin{array}{c}b \\
\text { TI }\end{array}$ & $\begin{array}{c}L_{50}(\mathrm{~cm} \mathrm{TL}) \\
\mathrm{RI}\end{array}$ & $\begin{array}{c}b \\
\mathrm{RI}\end{array}$ & $n$ \\
\hline 2005 & January & 33.88 (1.32) & $0.82(0.032)$ & $35.72(0.99)$ & $0.32(0.009)$ & 6783 \\
\hline 2006 & January & 33.44 (1.59) & $0.70(0.033)$ & $35.55(1.28)$ & $0.25(0.008)$ & 3984 \\
\hline 2007 & January & $32.69(2.18)$ & $0.77(0.051)$ & $34.57(1.34)$ & $0.16(0.005)$ & 5582 \\
\hline 2008 & January & 34.53 (1.38) & $0.62(0.025)$ & $38.01(0.99)$ & $0.22(0.006)$ & 6988 \\
\hline 2009 & January & 34.26 (1.53) & $0.92(0.041)$ & $37.37(0.99)$ & $0.27(0.007)$ & 7900 \\
\hline 2010 & January & 33.19 (1.29) & $1.01(0.039)$ & $36.37(0.87)$ & $0.21(0.005)$ & 3437 \\
\hline 2011 & January & $32.22(1.23)$ & $0.63(0.024)$ & $35.84(0.92)$ & $0.23(0.006)$ & 6377 \\
\hline 2012 & January & $33.04(1.20)$ & $0.87(0.031)$ & $35.34(0.81)$ & $0.29(0.006)$ & 9501 \\
\hline 2013 & January & $33.13(0.80)$ & $0.79(0.019)$ & $36.48(0.61)$ & $0.26(0.004)$ & 14136 \\
\hline 2005 & August & 34.45 (1.58) & $0.64(0.029)$ & & & 3228 \\
\hline 2007 & August & 34.51 (1.81) & $0.83(0.043)$ & & & 4371 \\
\hline 2011 & August & 32.39 (1.38) & $0.91(0.038)$ & & & 5577 \\
\hline 2012 & August & 34.26 (1.77) & $0.92(0.047)$ & & & 3030 \\
\hline 2013 & August & 33.35 (1.32) & $0.91(0.035)$ & & & 7392 \\
\hline
\end{tabular}

\section{Table 3}

Age at maturity $\left(A_{50}\right)$ and slope $(b)$ determined with the logistic model for female Argentine hake (Merluccius hubbsi) from the Patagonian stock collected during research surveys conducted off Argentina during January for the years 2005-2013. Coefficients of the models were estimated according to the following 2 interpretations: 1) the traditional interpretation, in which females in the resting stage were classified as mature, and 2) the revised interpretation, in which females in the resting stage were considered to be functionally immature. Standard errors of the means are given in parentheses. $n=$ sample size. TI, traditional interpretation; RI, revised interpretation.

\begin{tabular}{lccccc}
\hline Year & $A_{50}($ years $)$ & $b$ & $A_{50}($ years $)$ & $b$ & \\
& TI & TI & RI & \\
\hline 2005 & $2.40(0.11)$ & $4.62(0.22)$ & $2.74(0.12)$ & $2.57(0.11)$ & 2300 \\
2006 & $2.36(0.11)$ & $4.74(0.22)$ & $2.86(0.12)$ & $1.99(0.08)$ & 2516 \\
2007 & $2.32(0.16)$ & $5.80(0.44)$ & $3.16(0.16)$ & $1.07(0.05)$ & 1961 \\
2008 & $2.48(0.14)$ & $4.69(0.28)$ & $3.36(0.14)$ & $1.32(0.06)$ & 1924 \\
2009 & $2.50(0.12)$ & $5.60(0.29)$ & $2.95(0.14)$ & $2.40(0.12)$ & 1908 \\
2010 & $2.43(0.12)$ & $5.34(0.26)$ & $2.84(0.15)$ & $1.49(0.07)$ & 2027 \\
2011 & $2.34(0.14)$ & $3.96(0.27)$ & $2.79(0.12)$ & $1.87(0.08)$ & 1953 \\
2012 & $2.51(0.09)$ & $5.02(0.18)$ & $2.77(0.11)$ & $2.81(0.10)$ & 3414 \\
2013 & $2.47(0.08)$ & $4.95(0.17)$ & $2.87(0.10)$ & $2.21(0.08)$ & 3339 \\
& & & & & \\
\hline
\end{tabular}

pretation ranged between 2.32 and 2.50 years, while those estimated with the revised criterion increased to 2.74-3.36 years (Table 3).

The length-based maturity ogives estimated with data from January (spawning peak) and by using the traditional interpretation were significantly different
$(P<0.05)$ from those estimated by using data from August (resting period) of the same year, except for 2013 ( $P>0.05)$; in general, the $L_{50}$ coefficients were slightly higher in August, but the slopes were similar $(P>0.05)$ between months (Table 2, Fig. 2). When we compared the length-based maturity ogives estimated with data 


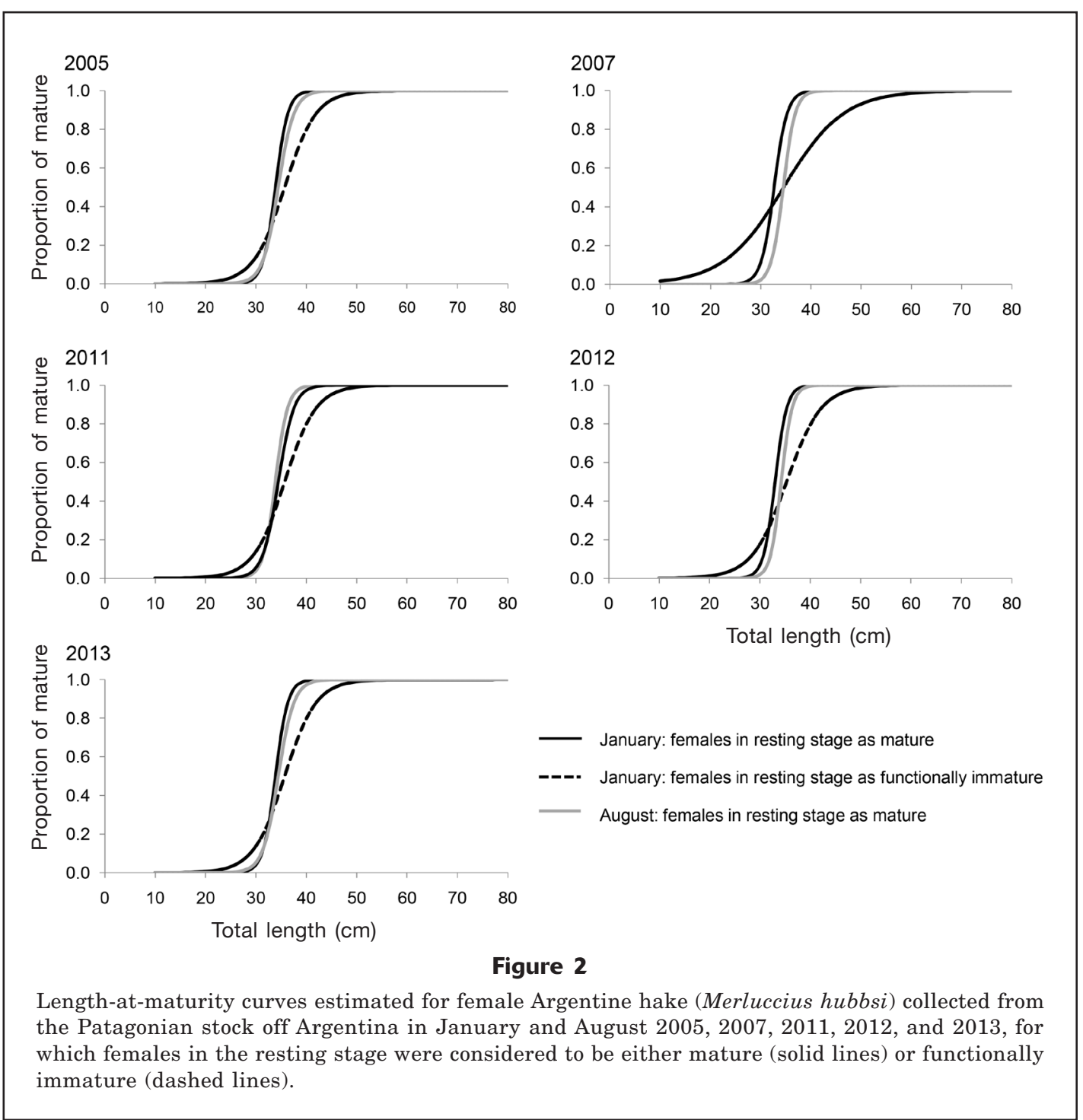

from January surveys and using the revised interpretation with those estimated in August of the same year, highly significant differences $(P<0.001)$ were observed, mainly in the slopes (Table 2, Fig. 2).

\section{Age and size distributions of females}

The length distributions of mature female Argentine hake showed considerable annual variation during the spawning peak in the period 2005-2013, and 1 or 2 modes (Fig. 3). In general, the main group of mature females was composed of individuals between $40 \mathrm{~cm}$ and $50 \mathrm{~cm} \mathrm{TL}$, but in some years, such as 2007 and 2008, a high frequency of females larger than $50 \mathrm{~cm} \mathrm{TL}$ was observed (Fig. 3). The latter figure also shows the fraction of the length distributions affected by SS when we used the maturity ogive estimated with the revised interpretation (Table 2). It was observed that females that would skip spawning are mainly specimens small- er than $50 \mathrm{~cm}$ TL, and have a modal size between 37 and $40 \mathrm{~cm}$ TL (Fig. 3).

Figure 4 shows the average age distributions obtained after grouping all years sampled and by applying the traditional interpretation of maturity and after considering the effect of skipped spawning. This figure confirms that females that would skip spawning were mainly younger specimens. Approximately $70 \%$ of females that skipped spawning were 3 years old.

\section{Reproductive potential}

Batch fecundity for female Argentine hake sampled in January between 2005 and 2013 ranged from 70,000 to $3,170,000$ hydrated oocytes, for fish between $29 \mathrm{~cm}$ and $95 \mathrm{~cm}$ TL. The relationship of batch fecundity to TL and to age for each sampled year fitted a power model (Table 4).

The number of oocytes produced by batch and by $1-\mathrm{cm}$ 


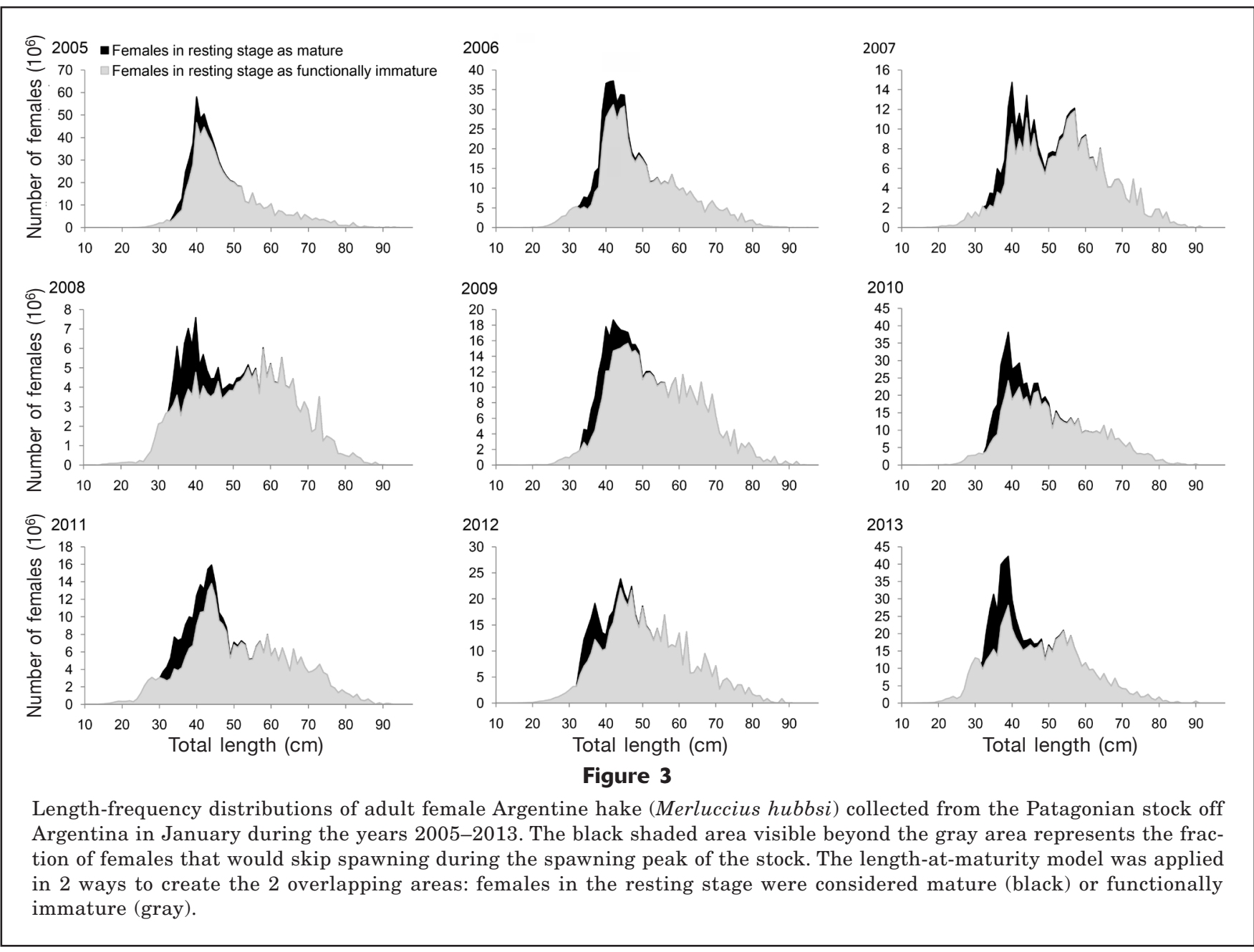

\section{Table 4}

Results of the regression analyses between batch fecundity (BF) and the variables total length (TL) and age for female Argentine hake (Merluccius hubbsi) sampled from the Patagonian stock during research surveys conducted off Argentina in January for the years 2005-2013. The letters $a$ and $b$ indicate the parameters of the equations; $r^{2}=$ coefficient of determination; $n=$ sample size.

\begin{tabular}{|c|c|c|c|c|c|c|c|c|}
\hline \multirow[b]{2}{*}{ Year } & \multicolumn{4}{|c|}{$B F=a\left(T L^{\mathrm{b}}\right)$} & \multicolumn{4}{|c|}{$B F=a\left(a g e^{\mathrm{b}}\right)$} \\
\hline & $a$ & $b$ & $r^{2}$ & $n$ & $a$ & $b$ & $r^{2}$ & $n$ \\
\hline 2005 & 0.66 & 3.39 & 0.87 & 90 & 21,750 & 1.99 & 0.70 & 82 \\
\hline 2006 & 2.32 & 3.06 & 0.73 & 95 & 26,830 & 1.83 & 0.70 & 89 \\
\hline 2007 & 1.59 & 3.20 & 0.84 & 78 & 30,169 & 1.87 & 0.64 & 77 \\
\hline 2008 & 1.27 & 3.24 & 0.84 & 81 & 19,793 & 2.09 & 0.68 & 81 \\
\hline 2009 & 1.58 & 3.19 & 0.76 & 91 & 21,251 & 2.04 & 0.66 & 89 \\
\hline 2010 & 0.96 & 3.30 & 0.78 & 102 & 22,492 & 1.91 & 0.70 & 100 \\
\hline 2011 & 2.37 & 3.07 & 0.81 & 80 & 22,422 & 1.90 & 0.68 & 75 \\
\hline 2012 & 0.31 & 3.59 & 0.84 & 98 & 17,326 & 2.02 & 0.66 & 98 \\
\hline 2013 & 1.39 & 3.22 & 0.85 & 83 & 25,350 & 1.83 & 0.71 & 82 \\
\hline
\end{tabular}




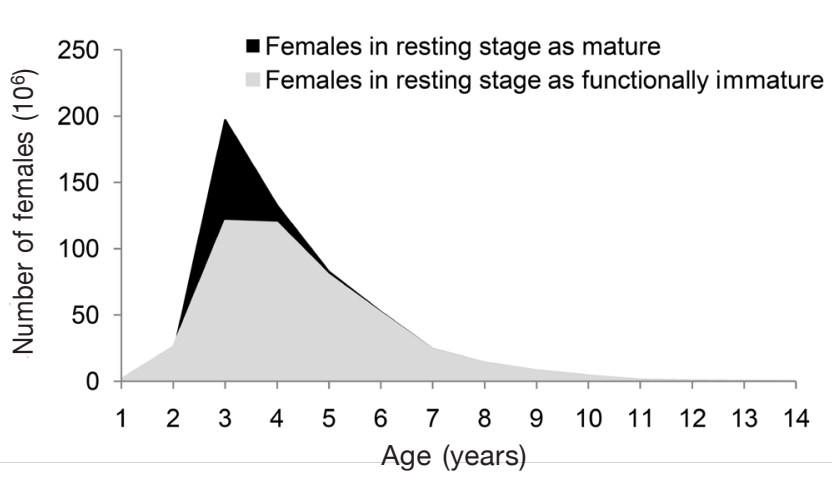

Figure 4

Age-frequency distributions obtained for adult female Argentine hake (Merluccius hubbsi) collected from the Patagonian stock off Argentina during January 2005-2013, averaged across years. The black area represents the fraction of females that would skip spawning during the spawning peak of the stock. The age-at-maturity model was applied in 2 ways to create the 2 overlapping areas: females in the resting stage were considered mature (black) or functionally immature (gray). length classes during the spawning peak in January varied annually during the period 2005-2013 (Fig. 5). During most years, the egg production depended on females larger than $50 \mathrm{~cm}$ TL, except in 2005 and 2006, when the abundance of smaller adult individuals was particularly high (Fig. 3). After considering the incidence of SS in the estimate of egg production by length class, it was evident that the SS phenomenon affected mainly females smaller than $50 \mathrm{~cm}$ TL (Fig. 5). The reduction in egg production of one batch ranged from $2.70 \%$ to $6.80 \%$ when we compared egg production by length class (Fig. 6). The lowest value in the reduction of egg production during the period analyzed was observed in 2012 , and it was coincident with a low proportion of females that had skipped spawning (Fig. 3).

The analysis of egg production by age class, after both interpretations of maturity were applied, confirmed that SS is observed mainly in young females (Fig. 7). In this case, the reduction in egg production of one batch on account of SS ranged from $3.56 \%$ to $12.12 \%$. As found with the comparison by length class, 2012 was the year with the lowest egg production by age class (Fig. 6).

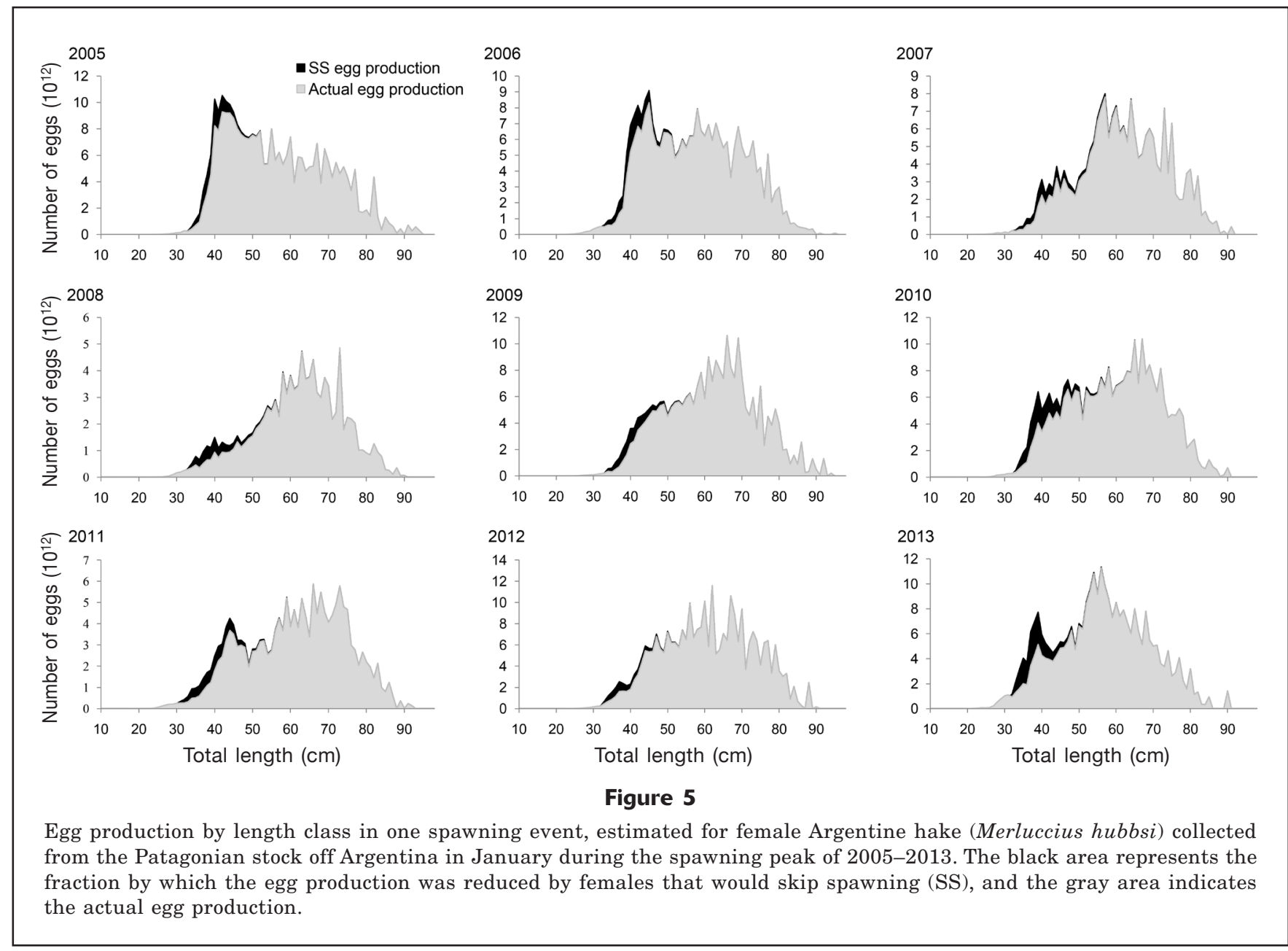




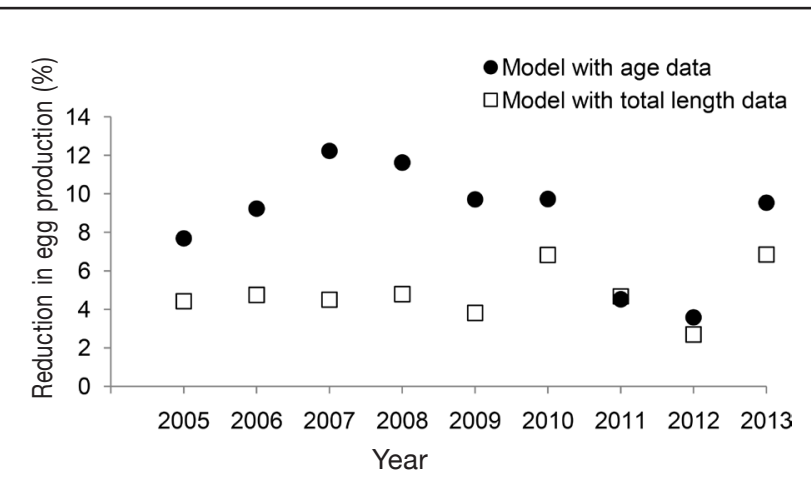

Figure 6

Reduction in egg production (\%) caused by female Argentine hake (Merluccius hubbsi) that would skip spawning during the spawning peak of the Patagonian stock during the period 2005-2013. The black circles indicate percentages obtained from the model in which age was used, and the open squares indicate percentages from the model in which total length was used.

\section{Discussion}

The interruption in gonad maturation during the reproductive cycle has been reported in different fish populations for over 40 years (Rideout et al., 2005), but more recently, SS has been recognized as potentially having important implications for the reproductive output of a population (Livingston et al., 1997; Trippel, 1999; Rideout et al., 2000). Clearly, there is a negative effect on egg production when a proportion of the adult fish does not spawn during an entire year. Therefore, failure to consider females that skip spawning may lead to an overestimation of the actual number of spawning individuals and affect calculations of reproductive potential of a stock.

In the case of Argentine hake, data collected from the primary reproductive area of the Patagonian stock reveal the presence of nonreproductive adult females during the spawning season (Macchi et al., 2004; Pájaro et al., 2005). Recently, Macchi et al. (2016) reported that of the 3 types described for the process of skipped spawning (retaining, reabsorbing, and resting)

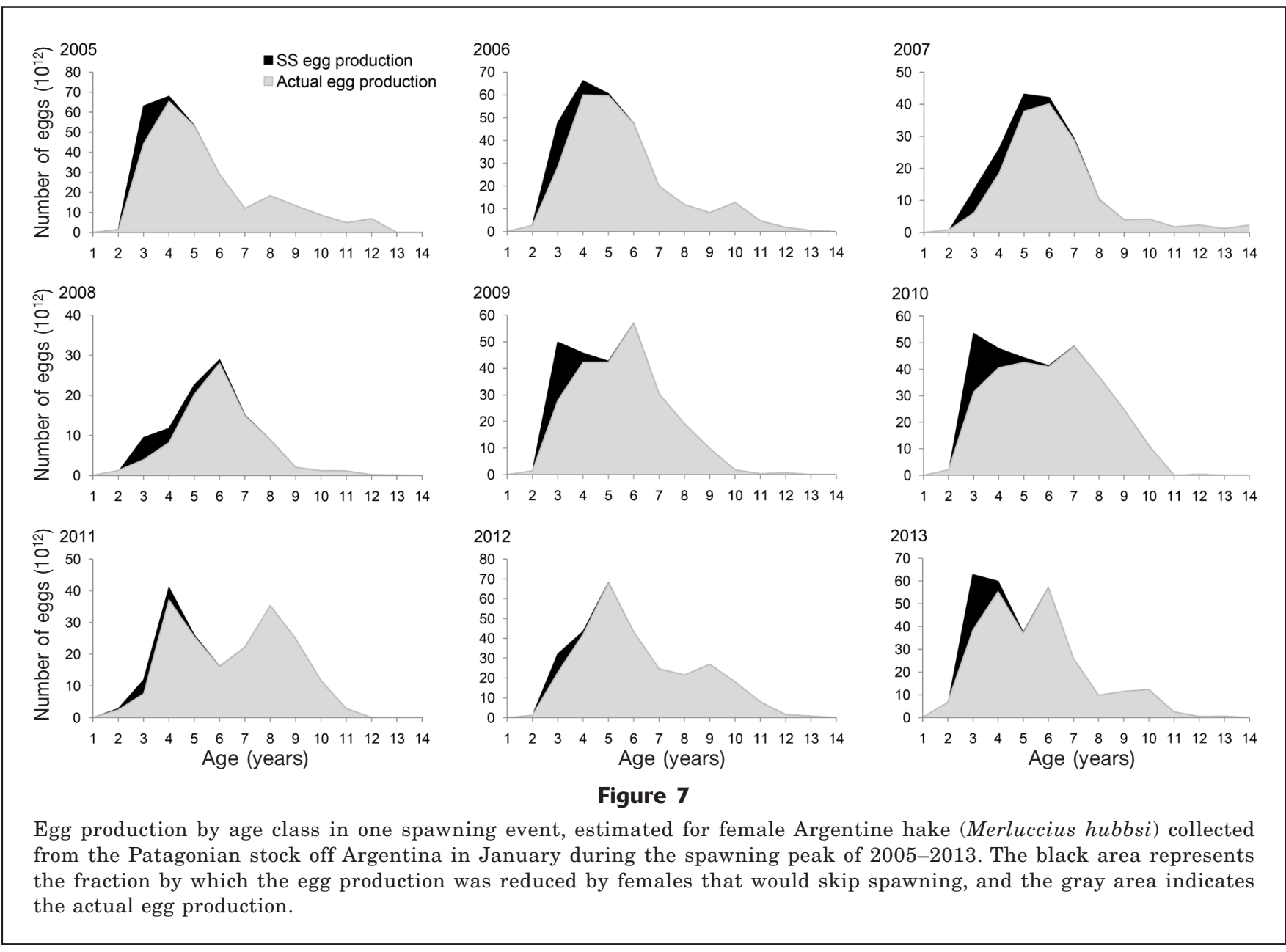


by Rideout et al. (2005), only the resting stage can be found in the Patagonian stock. When SS was included in the estimate of the maturity ogives of Argentine hake, it was shown that both $L_{50}$ and $A_{50}$ were affected by this phenomenon. After accounting for skipped spawning (i.e., considering females at resting stage to be functionally immature individuals), the size at first maturity increased by $2-3 \mathrm{~cm}$ TL compared with values obtained with the traditional interpretation of maturity assignment, where females in a resting stage are considered mature individuals. Even so, most $L_{50}$ values estimated with the revised interpretation for the period 2005-2013 were close to $35 \mathrm{~cm}$ TL, which is the length class traditionally used to differentiate between juveniles and adults in commercial catches of Argentine hake to define protected areas for this species (Dato et al. ${ }^{4}$ ).

In the case of age at first maturity, this coefficient increased by $0.27-0.88$ years when the proportion of females that would skip spawning was incorporated. This represents an increase between $10 \%$ and $25 \%$ over the value obtained with the traditional interpretation. However, these differences in $A_{50}$ were low compared with those reported for sablefish (Anoplopoma fimbria) by Rodgveller et al. (2016), who estimated an increase of $A_{50}$ of approximately $30 \%$ when females that would skip spawning were considered to be functionally immature individuals. The maturity models for Argentine hake, both for size and age, showed a decrease of the slopes when the SS effect was included in the estimations, indicating that the age and size at which $100 \%$ of individuals reach sexual maturity are greater than those calculated by the traditional interpretation.

Analysis of the size and age structure of Argentine hake confirms that nonreproductive adult females are mainly young specimens with sizes ranging between 40 and $50 \mathrm{~cm} \mathrm{TL}$, corresponding primarily with 3-year-old fish, as was previously reported (Macchi et al., 2016). The 3-year-old age class constitutes approximately $70 \%$ of the female Argentine hake that would skip spawning; therefore, it is the main age class affecting the reduction in egg production. If the estimates of $A_{50}$ (Table 3) are taken into account, it is possible that a large proportion of females that have already experienced their first annual spawning could skip the next spawning cycle, probably because of deficiencies in their nutritional condition (Macchi et al., 2016). It is also possible that some females that skip spawning are actually juveniles that had not yet reached sexual maturity. However, for the purposes of estimating $L_{50}$ or $A_{50}$, this error in determining maturity would gener-

\footnotetext{
${ }^{4}$ Dato, C., G. Álvarez Colombo, and G. J. Macchi. 2013. Evaluación de los juveniles y stock desovante de merluza (Merluccius hubbsi) en la zona de cría norpatagónica. Resultados obtenidos en la campaña de enero de 2013 y comparación con los resultados del período 2005-2012. Inf. Téc. Of. 12, 25 p. [Available from Instituto Nacional de Investigación y Desarrollo Pesquero, Paseo Victoria Ocampo Nro. 1, B7602HSA Mar del Plata, Argentina].
}

ate the same bias as SS because juveniles and adults in the resting stage are both functionally immature. In other cases, when skipped spawning has been reported, it has been observed that this phenomenon affects primarily younger adult individuals, as in the case of Atlantic herring (Clupea harengus; Engelhard and Heino, 2005) and Atlantic cod (Gadus morhua) from the Arctic (Jørgensen et al., 2006) and from the Atlantic (Rideout and Rose, 2006).

The $L_{50}$ ogives of the Patagonian stock of Argentine hake from the resting period (August) were more similar to those based on the previous spawning peak of January, when fish that would skip spawning were classified as mature, than when fish that would skip spawning were classified as functionally immature. These results indicate that specimens identified as adults in January, during spawning, show the same maturity characteristics 7 months later (August), when the maturity ogive basically differentiates between juveniles and adults at the resting stage. This finding reinforces the idea that females that would skip spawning in January are adults, not juveniles.

The difference in egg production values by age class estimated in January with the traditional criterion, and considering spawning omission, ranged between $3.56 \%$ and $12.12 \%$ over the period $2005-2013$. That is, if the objective is to estimate the reproductive potential of Argentine hake by using the $A_{50}$ ogive, in some years there would be an overestimation close to $12 \%$ for this variable. However, when the egg production by length class during January is considered over the same period, the percentages of reductions in egg production resulting from SS were much lower than those estimated from the age-based model, ranging between $2.70 \%$ and $6.80 \%$. The differences between the lengthand age-based models in the percentages of reduction in egg production caused by SS may be associated with the variability explained by each model. The $A_{50}$ model, which groups different length classes in each age class, embodies greater variability than the maturity relationship with total length. On the other hand, fewer samples were used to estimate the $A_{50}$ curves than the number of samples used to determine $L_{50}$ (Tables 2 and 3 ) and consequently would be expected to generate a better model fit for length over age.

The relatively low levels of reduction in egg production caused by SS for Argentine hake in our study indicate that the effect of skipped spawning in the Patagonian stock may be less significant than that reported for other species. For example, regarding Atlantic cod, Rideout and Rose (2006) suggested an overestimation of reproductive potential near $40 \%$ if the proportion of SS was not taken into account. Kennedy et al. (2014) reported that failure to properly interpret the maturity scale in Greenland halibut (Reinhardtius hippoglossoides) could lead to an overestimation of spawning stock biomass between $28 \%$ and $92 \%$, depending on areas and years, whereas Núñez et al. (2015) calculated an overestimation of approximately $20 \%$ for the same species. In Argentine hake, it seems that the overestima- 
tion of reproductive potential could be even lower than expected because in this species, females that would skip spawning are primarily young individuals. Macchi et al. $(2006,2013)$ suggested that young ( $<5$ years old) female Argentine hake produce eggs of poorer quality than eggs spawned by older females. In addition, it was reported that the extent of the spawning season in young females of this species is shorter than that in old individuals ( $>5$ years old), and a lower number of spawning events occur during the reproductive season (Macchi et al., 2004). Therefore, it is possible that the recruitment success of this stock depends mainly on "big, old, fat, fecund female fish" (BOFFFF hypothesis, Berkeley et al., 2004) rather than on young spawners, as was suggested for many species, including the deepwater hake (Merluccius paradoxus) in southern Africa (Field et al., 2008).

\section{Acknowledgments}

We wish to thank to the technical staff of the Hake Assessment Group of the INIDEP for age determination. We wish to express our gratitude for the corrections made by reviewers that greatly improved the manuscript. This work was supported by the INIDEP, Consejo Nacional de Investigaciones Científicas y Técnicas (CONICET; PIP 112201201 00047), and Fondo para la Investigación Científica y Tecnológica (FONCyT; PICT-2013-1484). This article is INIDEP contribution no. 2052.

\section{Literature cited}

Berkeley, S. A., M. A. Hixon, R. J. Larson, and M. S. Love. 2004. Fisheries sustainability via protection of age structure and spatial distribution of fish populations. Fisheries 29(8):23-32. Article

Dutil, J.-D.

1986. Energetic constraints and spawning interval in the anadromous Arctic charr (Salvelinus alpinus). Copeia 1986:945-955. Article

Draper, N. R., and H. Smith.

1981. Applied regression analysis, $2^{\text {nd }}$ ed., 709 p. John Wiley \& Sons Inc., New York.

Engelhard, G. H., and M. Heino.

2005. Scale analysis suggests frequent skipping of the second reproductive season in Atlantic herring. Biol. Lett. 1:172-175. Article

Field, J. G., C. L. Moloney, L. du Buisson, A. Jarre, T. Stroemme, M. R. Lipinski, and P. Kainge.

2008. Exploring the BOFFFF hypothesis using a model of southern African deepwater hake (Merluccius paradoxus). In Fisheries for global welfare and environment: memorial book of the 5th World Fisheries Congress 2008 (K. Tsukamoto, T. Kawamura, T. Takeuchi, T. D. Beard Jr., and M. J. Kaiser, eds.), p. 17-26. Terrapub, Tokyo, Japan.

Holmgren, K.

2003. Omitted spawning in compensatory-growing perch. J. Fish Biol. 62:918-927. Article
Hunter, J. R., N. C. H. Lo, and R. J. H. Leong.

1985. Batch fecundity in multiple spawning fishes. In An egg production method for estimating spawning biomass of pelagic fish: application to the northern anchovy, $E n$ graulis mordax (R. Lasker ed.), p. 67-77. NOAA Tech. Rep. NMFS 36.

Jørgensen, C., B. Ernande, Ø. Fiksen, and U. Dieckmann. 2006. The logic of skipped spawning in fish. Can. J. Fish. Aquat. Sci. 63:200-211. Article

Kendall, M. G., and A. Stuart.

1967. The advanced theory of statistics, 449 p. Charles Griffin and Co. Ltd., London.

Kennedy, J., R. B. Hedeholm, A. C. Gundersen, and J. Boje. 2014. Estimates of reproductive potential of Greenland halibut (Reinhardtius hippoglossoides) in East Greenland based on an update of maturity status. Fish. Res. 154:73-81. Article

Livingston, M. E., M. Vignaux, and K. A. Schofield.

1997. Estimating the annual proportion of nonspawning adults in New Zealand hoki, Macruronus novaezelandiae. Fish. Bull. 95:99-113.

Macchi, G. J., M. Pájaro, and M. Ehrlich.

2004. Seasonal egg production pattern of the Patagonian stock of Argentine hake (Merluccius hubbsi). Fish. Res. 67:25-38. Article

Macchi, G. J., M. Pájaro, M. I. Militelli, N. Radovani, and L. Rivas.

2006. Influence of size, age and maternal condition on the oocyte dry weight of Argentine hake (Merluccius hubbsi). Fish. Res. 80:345-349. Article

Macchi, G. J., E. Leonarduzzi, M. V. Diaz, M. Renzi, and K. Rodrigues.

2013. Maternal effects on the fecundity and egg quality of the Patagonian stock of Argentine hake (Merluccius hubbsi). Fish. Bull. 111:325-336. Article

Macchi, G. J., M. V. Diaz, E. Leonarduzzi, M. I. Militelli, and $\mathrm{K}$. Rodrigues.

2016. Skipped spawning in the Patagonian stock of Argentine hake (Merluccius hubbsi). Fish. Bull. 114:397-408. Article

Núñez, L. A., E. H. Hallfredsson, and I.-B. Falk-Petersen.

2015. Different maturity scales affect estimations of fecundity, TEP and spawning stock size of Greenland halibut, Reinhardtius hippoglossoides (Walbaum, 1792). Mar. Biol. Res. 11:824-833. Article

Pájaro, M., G. J. Macchi, and P. Martos.

2005. Reproductive pattern of the Patagonian stock of Argentine hake (Merluccius hubbsi). Fish. Res. 72:97-108. Article

Renzi M., and M. A. Pérez.

1992. Un criterio para la determinación de la edad en juveniles de merluza (Merluccius hubbsi) mediante la lectura de otolitos. Frente Marit. 11:15-31.

Rideout, R. M., and G. A. Rose.

2006. Suppression of reproduction in Atlantic cod Gadus morhua. Mar. Ecol. Progr. Ser. 320:267-277. Article

Rideout, R. M., and J. Tomkiewicz.

2011. Skipped spawning in fishes: more common than you might think. Mar. Coast. Fish. 3:176-189. Article

Rideout, R. M., M. P. M. Burton, and G. A. Rose.

2000. Observations on mass atresia and skipped spawning in northern Atlantic cod, from Smith Sound, Newfoundland. J. Fish Biol. 57:1429-1440. Article 
Rideout, R. M., G. A. Rose, and M. P. M. Burton.

2005. Skipped spawning in female iteroparous fishes. Fish Fish. 6:50-72. Article

Rideout, R. M., M. J. Morgan, and G. R. Lilly.

2006. Variation in the frequency of skipped spawning in Atlantic cod (Gadus morhua) of Newfoundland and Labrador. ICES J. Mar. Sci. 63:1101-1110. Article
Rodgveller, C. J., J. W. Stark, K. B. Echave, and P.-J. F. Hulson. 2016. Age at maturity, skipped spawning, and fecundity of female sablefish (Anoplopoma fimbria) during the spawning season. Fish. Bull. 114:89-102. Article

Trippel, E. A.

1999. Estimation of stock reproductive potential: history and challenges for Canadian Atlantic gadoid stock assessments. J. Northwest Atl. Fish. Sci. 25:61-81. 